\title{
Prioritization of Strategies for Development of Ecotourism by Means of Ahp-Swot on the Example of Kopaonik, Serbia
}

\author{
Milena Cvetkovići ${ }^{1 *}$, Mladen Šljivović ${ }^{2}$ \\ ${ }^{1}$ Faculty of Geography, University of Belgrade, Studentski trg 3/3, 11000 Belgrade, Serbia \\ ${ }^{2}$ Faculty of Management Zaječar, Park šuma kraljevića bb, 19000 Zaječar, Serbia
}

Received: 5 February 2021

Accepted: 12 April 2021

\begin{abstract}
A new trend has appeared in the last year in the sector of tourism-ecotourism as a response to the excessive use and exploitation of unrenewable natural resources. Simultaneously with this process, it is necessary to make strategies that would contribute to development in the best possible way. A combination of methods of multicriteria analysis (analytical hierarchical process (AHP) and SWOT analysis) has been used in this study in order to set prioritization of strategies. The main criteria on the basis of which valorisation has been done are: strengths, weaknesses, opportunities and threats. Elements of SWOT have been ranked into, by means of using the AHP method, and their relative weight has been determined. For check-up of weight coefficients by AHP method, degree of consistency of matrix has been used (CR). The procedure is previously described in detail, and later an example has been given for Kopaonik, the national park in Serbia.
\end{abstract}

Keywords: MCDM, Analytical Hierarchical Process (AHP), SWOT analysis, strategy of development of ecotourism

\section{Introduction}

Ecotourism is a relatively new concept in planning of tourism, and also its basic elements and dimensions have been discussed for decades backwards in studies about tourism and natural resources management [1]. Ecotourism is a fast growing sector when it comes to international touristic industry, and the „main ticket“ for destinations of international tourists who are looking for new experiences and challenges in surroundings.

*e-mail: milena.cvetkovic4@gmail.com
Protected areas are a challenge and opportunity for all potential ecotouristic destinations. National park Kopaonik, as a very important touristic area in Serbia, is one of potential ecotourism destinations.

Multicriteria decision making (MCDM) is a technique of decision making, which is implemented in various disciplines, such as operational research, management and engineering [2]. MCDM has found its implementation for solving of most various and complex problems of decision making [3]. [4] describe multi-criteria decision making as a process of choosing one from the set of available alternatives, on the basis of the set of criteria of usually different importance. 
[5] cite that the purpose of MCDM method is the assessment and selection of adequate alternative on the basis of several criteria by using systematic analysis which exceeds limitations of non-structural individual or group decision making.

In this work, SWOT analysis has been upgraded by combining classical methods of multicriteria analysis on the basis of which integrated AHP-SWOT has been defined for valorization of potential of the national park Kopaonik and prioritization of strategies of development of ecotourism of the abovementioned space.

In continuation of this work, a survey of research so far will be presented first, then integrated AHP-SWOT methods will be explained, together with all the steps that have to be carried out into action so that it would be implemented. In chapter 4 AHP-SWOT, the method will be implemented for prioritization of strategies of development of ecotourism in the national park Kopaonik. Results will be presented in conclusion.

\section{A surevay of Research so Far}

Since ecotourism is based on nature, protected areas will testify about increasingly bigger pressure by tourists, quality of destination attributes has a significant influence on their experience. [6] use the method of analytical hierarchical process (AHP) for the assessment of adequacy of locations for ecotourism in Oman (Masirah island). Thirteen criteria have been identified on the basis of inspection of literature, local knowledge and field work.

[7] as a case study, used web pages of national parks in Greece. In processing results they used the AHP method. Furthermore, it is currently recognized that so called "informational accessibility" (quality websites and exposure on social medias) are important factor in stimulating the development of tourism in national parks, which leads to raising of awareness for the protected area and region [8]. [8] concluded that cases of "no data" for tourism accommodation in the local data bank can cause a "lack of tourism attractiveness" according to the methodology they applied. [9] analyzed websites for booking hotels, also by using the AHP methodology for ranking results.

[10] combined classical and phase methods of multicriteria analysis, i.e. upgraded SWOT analysis and defined integral SWOT-ANP-FANP for prioritization of strategies of sustainable development at the National park Djerdap. Final results present the chronological order of implementation of generated strategies for development of ecotourism, by which preservation of natural and anthropogenic rerouces and environment protection at the National park Djerdap is achieved.

[11] assess prospects for the development of ecotourism in Calabria (Southern Italy). Starting from the explanation of protected area, the work develops the concept of ecotourism which enables to local communities use from the abovementioned kind of tourism. Hybrid A'WOT model is implemented in the study, at which different strategies can be formulated, in order to evaluate the elements of SWOT analysis.

[12] did the study on the example of Iznik - ancient Greek, Roman, Byzantine and Osman city, with its lake, hystorical walls and gates, churches and mosques from the early period (it has a different status of a protected area). Field research has been done for that purpose, interviews, poll study (analysis of multiple criteria) and SWOT analysis with local citizens, experts and tourists.

[13], estimated and unified the potential for development for ecotourism in Mariwan (Iran) by using fuzzy, FANP and TOPSIS. [14] use A'WOT model for determining sustainable strategic plans determined for planning of public green surfaces in Nigde (Turkey). [15], in their study analyze strategy of development of the area of the old city Semarang (Indonesia), by using AHP-SWOT methodology. [16] did a similar research.

[17] analyzed challenges and perspectives for sustainable development of cultural industry in Chinese province Shaanxi, by using SWOT analysis and analytical hierarchical process (AHP). [18] also use AHP-SWOT method. On the basis of 25 survey studies of industrial experts, this study uses the above mentioned for analysis of strengths, weaknesses, possibilities and threats to rural development and determines the strategy of development of rural China. [19] highlights that present touristic activities in Bangladesh are unsustainable and snows the way of sustainable development of touristic industry in Bangladesh, by using SWOT analysis and TOWS matrix.

\section{Material and Methods}

Integrated AHP-SWOT (or A'WOT) combines analytical hierarchical process (AHP) and SWOT (strength, weaknesses, possibilities and threats) analysis.

According to [15], SWOT analysis should be based on two main categories:

1. Analysis of internal factors (analysis of strengths and weaknesses of internal surroundings under whose influence they are). Strenghts and weaknesses are factors in the systems which could prevent organization to realize its set goal.

2. Analysis of external factors (analysis of possibilities and threats relevant for external surroundings). Opportunities and threats are considered exogenous factors which facilitate and limit systems in achiement of goals).

Analytical hierarchical process (AHP) is a theory of measuring, through paired comparison and relies on assessment of experts on the basis of the priority scale [20]. Due to simplicity and easiness of use, AHP is a popular method which is used by many decision-makers [21].

Generally observed, decision makers compares elements in the given level of hierarchy in relation to 
Table 1. Saaty's scale.

\begin{tabular}{|c|c|c|}
\hline $\begin{array}{c}\text { Evaluation } \\
\text { scale }\end{array}$ & Definition & Explanation \\
\hline 1 & Equal value & Two activities of equally contribute to aim \\
\hline 3 & Modest importance & $\begin{array}{l}\text { Experience and assessment mildly favorize one } \\
\text { activity in relation to other }\end{array}$ \\
\hline 5 & Strong importance & $\begin{array}{c}\begin{array}{c}\text { Experience and assessment strongly favorize one } \\
\text { criterion }\end{array}\end{array}$ \\
\hline 7 & Demonstrated value & $\begin{array}{c}\text { One criterion is considerably more favorized than } \\
\text { the other }\end{array}$ \\
\hline 9 & Absolute value & $\begin{array}{l}\text { Proofs favorizing one activity in relation to other } \\
\text { are of the highest possible rank of affirmation }\end{array}$ \\
\hline $2,4,6,8$ & Intervalues & When compromise is necessary \\
\hline $\begin{array}{l}\text { Reciprocal } \\
\text { values }\end{array}$ & $\begin{array}{l}\text { If one activity has some of upper numbers (for example, } 5 \text { ) } \\
\text { in comparison to other activity, then the other value has a } \\
\text { reciprocal value, i.e. }(1 / 5) \text { when it is compared to the other. }\end{array}$ & \\
\hline $1,1-1,9$ & If activities are very equalled & $\begin{array}{l}\text { It is difficult to determine equal value, but } \\
\text { a relative value can be marked of a certain crite- } \\
\text { rion with another }\end{array}$ \\
\hline
\end{tabular}

Source: Saaty L. Thomas, 2008

all subordinate elements in the higher level of hierarchy. Every comparison is made by giving of numerical assessment according to already mentioned Saaty's scale (Table 1).

Numerical grades of comparison of pairs of elements on the given level of hierarchy are entered into the matrix of comparison which is reciprocal, i.e., elements from the upper triangle are symmetrically reciprocal to elements from the upper angle, while elements on the main diagonal are equal 1.

For every pair of criteria (B1, B2, B3...), value of domination of one criterion in relation to the other is determined. Illustrated example is given in Table 2. Element $a_{i j}$ presents a comparative advantage $\mathrm{B}_{i}$ in comparison with $\mathrm{B}_{j}$ by use of fundamental scale. At filling in the matrix a rule is valid that the element $b_{i j}$ has the value 1 for $\mathrm{i}=\mathrm{j}$, as well as that $b_{i j}=1 / b_{i j}$.

After that, the normalized weight $\mathrm{w}_{j}$ is calculated using the geometric mean method, which is shown by the following formulae:

$$
\mathrm{GM}_{\mathrm{j}}=\left(\prod_{\mathrm{i}=1}^{\mathrm{n}} \mathrm{a}_{\mathrm{ij}}\right)^{1 / \mathrm{n}}
$$

Table 2. Matrix of comparison in pairs.

\begin{tabular}{|c|c|c|c|c|c|}
\hline & $\mathrm{B}_{1}$ & $\mathrm{~B}_{2}$ & $\mathrm{~B}_{3}$ & $\ldots$ & $\mathrm{B}_{j}$ \\
\hline $\mathrm{B}_{1}$ & $b_{11}$ & $b_{12}$ & $b_{13}$ & $\ldots$ & $b_{1 j}$ \\
\hline $\mathrm{B}_{2}$ & $b_{21}$ & $b_{22}$ & $b_{23}$ & $\ldots$ & $b_{2 j}$ \\
\hline$\ldots$ & $\ldots$ & $\ldots$ & $\ldots$ & $\ldots$ & $\ldots$ \\
\hline $\mathrm{B}_{j}$ & $b_{j 1}$ & $b_{j 2}$ & $b_{j 3}$ & $\ldots$ & $b_{i j}$ \\
\hline
\end{tabular}

Source: Saaty L. Thomas, 2008

$$
w_{j}=G_{j} / \sum_{i=1}^{n} G_{j}
$$

...where $\mathrm{GM}_{i}$ is a geometric mean, and $\mathrm{w}_{j}$ is the weight of the $\mathrm{j}$-th criterion.

After that the degree of consistency is calculated. In order to calculate the degree of consistency, maximum own value of the matrix $\lambda_{\max }$ i should first be determined and on the basis of it the index of consistency $\mathrm{Ci}$ and with the following formula:

$$
\mathrm{Ci}=\left(\lambda_{\max }-\mathrm{n}\right) /(\mathrm{n}-1)
$$

...where $\mathrm{n}$ is the number of criteria that are compared.

We calculate the degree of consistency according to a following formula:

$$
\mathrm{Cr}=\mathrm{Ci} / \mathrm{Ri}
$$

...where $\mathrm{Ri}$ is the accidental index of considency whose values are given in Table 3.

If the degree of consistency (CR) is less than 0,10 , the result is accurate enough and there is no need for corrections in comparisons and repeating of calculations. If the degree of consistency is bigger than 0,10 , results should be analyzed again and establish the reasons for inconsistencies, and if the repetition of the procedure in several steps does not lead to lowering of the degree of consistency to the tolerant limit 0,10 , all results should be rejected and whole procedure repeated.

A'WOT method has been used in this work, and TOWS matrix to suggest sustainable strategies for development of ecotourism in the national park Kopaonik. The very procedure is as follows. First, 
Table 3. Accidental indices.

\begin{tabular}{|c|c|c|c|c|c|c|c|c|c|}
\hline The order of the matrix & 1 & 2 & 3 & 4 & 5 & 6 & 7 & 8 & 9 \\
\hline Ri & 0,00 & 0,00 & 0,58 & 0,90 & 1,12 & 1,24 & 1,32 & 1,41 & 1,45 \\
\hline
\end{tabular}

Source: Saaty L. Thomas, 2008

Table 4. Determining of global weights of SWOT analysis.

\begin{tabular}{|c|c|c|c|c|}
\hline SWOT group & Weight of the group & SWOT & Weight of the elements of the group & Resulting weights \\
\hline \multirow{3}{*}{ Strenghts } & \multirow{3}{*}{$\mathrm{S}$} & $\mathrm{S}_{1}$ & $\mathrm{~W}_{\mathrm{s} 1}$ & $\mathrm{~W}_{\mathrm{r}} \mathrm{s}_{1}$ \\
\hline & & $\mathrm{S}_{2}$ & $\mathrm{~W}_{\mathrm{s} 2}$ & $\mathrm{~W}_{\mathrm{r}} \mathrm{s}_{2}$ \\
\hline & & $\ldots$ & $\cdots$ & $\ldots$ \\
\hline \multirow{3}{*}{ Weaknesses } & \multirow{3}{*}{$\mathrm{W}$} & $\mathrm{W}_{1}$ & $\mathrm{~W}_{\mathrm{w} 1}$ & $\mathrm{~W}_{\mathrm{r}} \mathrm{W}_{1}$ \\
\hline & & $\mathrm{W}_{2}$ & $\mathrm{~W}_{\mathrm{w} 2}$ & $\mathrm{~W}_{\mathrm{r}} \mathrm{w}_{2}$ \\
\hline & & $\cdots$ & $\cdots$ & $\ldots$ \\
\hline \multirow{3}{*}{ Opportunities } & \multirow{3}{*}{$\mathrm{O}$} & $\mathrm{O}_{1}$ & $\mathrm{~W}_{\mathrm{o} 1}$ & $\mathrm{~W}_{\mathrm{r}} \mathrm{O}_{1}$ \\
\hline & & $\mathrm{O}_{2}$ & $\mathrm{~W}_{\mathrm{o} 2}$ & $\mathrm{~W}_{\mathrm{r}} \mathrm{O}_{2}$ \\
\hline & & $\ldots$ & $\cdots$ & $\cdots$ \\
\hline \multirow{3}{*}{ Threats } & \multirow{3}{*}{$\mathrm{T}$} & $\mathrm{T}_{1}$ & $\mathrm{~W}_{\mathrm{t} 1}$ & $\mathrm{~W}_{\mathrm{r}} \mathrm{t}_{1}$ \\
\hline & & $\mathrm{T}_{2}$ & $\mathrm{~W}_{\mathrm{t} 2}$ & $\mathrm{~W}_{\mathrm{r}} \mathrm{t}_{2}$ \\
\hline & & $\cdots$ & $\cdots$ & $\cdots$ \\
\hline
\end{tabular}

Source: Osuna and Aranda (2007)

SWOT analysis has been done, to determine the weight of every individual elements, within the SWOT matrix. For that purpose, questionnaries have been created, filled in by experts.

Best ranked elements from every SWOT group are mutally compared with the aid of AHP method and in this way weight factors of the whole group are obtained $(\mathrm{S}, \mathrm{W}, \mathrm{O}$ and $\mathrm{T})$. The resulting weight $\left(\mathrm{W}_{\mathrm{rsi}}, \mathrm{W}_{\mathrm{rwi}}, \mathrm{W}_{\text {roi }}\right.$ and $\mathrm{W}_{\mathrm{rti}}$ ) is obtained by multiplying of the weight group (S, W, O and T) with the weight of the elements within the group $\left(w_{s i}, \mathrm{w}_{\mathrm{wi}}, w_{o i}\right.$ and $\left.w_{t i}\right)$, demonstrated by the formulas 1, 2, 3 and 4. Final results are presented in tables (Table 4) [22].

$$
\begin{gathered}
\mathrm{W}_{\mathrm{rsi}}=\mathrm{S} \times \mathrm{w}_{\mathrm{si}} \\
\mathrm{W}_{\mathrm{rwi}}=\mathrm{W} \times \mathrm{w}_{\mathrm{wi}} \\
\mathrm{W}_{\mathrm{roi}}=\mathrm{O} \times \mathrm{w}_{\mathrm{oi}} \\
\mathrm{W}_{\mathrm{rti}}=\mathrm{T} \times \mathrm{w}_{\mathrm{ti}}
\end{gathered}
$$

The last step is the selection of strategies which seem the best and the most accessible for development of ecotourism in geospatial encompassing of research space. In formulation of strategy, care should be taken of goals that should be formulated in such way to be realistic and consistent, done in a hierarchical way and if possible expressed in a quantitative way [23]. In that case, TOWS is used (Threats, Opportunities, Weaknesses, Strengths) matrix. TOWS matrix is essentially a changed order of SWOT analysis, i.e., starts from defined elements of the SWOT analysis, and afterwards, on the basis of them, strategies based on interior factors and their response to exterior factors are formulated.

TOWS matrix formulates 4 different strategies:

1. SO - internal strength can be used for realization of external possibilities (ideal case)

2. WO - decrease internal weakness

3. ST - internal strategy which is used for minimizing of the internal threats

4. WT - to decrease internal weakness and avoid external threat (self-defense strategy, in worst case). (Table 5) [24].

After calculating the priorities of the SWOT factor using AHP method, strategies can develop in accordance with information obtained from this comparison. In this phase, alternative strategies for development of ecotourism have been presented, taking into consideration internal and external factors derived from SWOT analysis.

[25], after setting strategies it is necessary to again observe factors that are found in the SWOT analysis and calculate how efficient they are to a certain element. In expert analysis, efficiencies of strategies towards 
Table 5. TOWS matrix.

\begin{tabular}{|c|c|c|}
\hline & External chances (opportunities) & External threats \\
\hline Internal strengths & $\begin{array}{c}\text { Maxi-maxi strategy SO } \\
\text { Use internalstrengths (S) to use external } \\
\text { opportunities (O) }\end{array}$ & $\begin{array}{c}\text { Maxi-mini strategies ST } \\
\text { Rely on internal strengths (S) in order to } \\
\text { minimize dangers (T) }\end{array}$ \\
\hline External weaknesses & $\begin{array}{c}\text { Mini-maxi WO } \\
\text { Mini-mini WT }\end{array}$ \\
$\begin{array}{c}\text { Strategies which minimize weaknesses (W) } \\
\text { to use the opportunities (O) }\end{array}$ & $\begin{array}{c}\text { Strategies which minimize weaknesses } \\
\text { (W) to decease dangers (T) }\end{array}$ \\
\hline
\end{tabular}

Source: Wickramasinge and Takano (2010)

elements from SWOT group are determined. Indexes of efficiency are obtained in that way.

$\mathrm{U}_{\mathrm{s}} \mathrm{i}_{\mathrm{j}}$ - efficiency of strategy $\mathrm{j}$ to use the advantages of the strategy $\mathrm{S}_{i}$

$U_{w i j}$ - efficiency of strategy $j$ to decrease weaknesses of $\mathrm{W}_{\mathrm{i}}^{\text {wij }}$

$\mathrm{U}_{\text {oij }}$ - efficiency of strategy $\mathrm{j}$ to use opportunities $\mathrm{O}_{\mathrm{i}}$

$\mathrm{U}_{\mathrm{tij}}^{\mathrm{oij}}$ - efficiency of strategy стратегије $\mathrm{j}$ in facing with threats $T_{i}$

Global value of $j$-th strategy $V_{j}$ can be defined with a formula:

$$
\begin{gathered}
\mathrm{V}_{\mathrm{j}}=\sum_{\mathrm{i}=1}^{\mathrm{K}} \mathrm{U}_{\mathrm{Sij}} \mathrm{W}_{\mathrm{rsi}}+\sum_{\mathrm{i}=1}^{\mathrm{L}} \mathrm{U}_{\mathrm{Wij}_{\mathrm{ij}}} \mathrm{W}_{\text {rwi }} \\
+\sum_{\mathrm{i}=1}^{\mathrm{M}} \mathrm{U}_{\mathrm{Oij}} \mathrm{W}_{\text {roi }}+\sum_{\mathrm{i}=1}^{\mathrm{N}} \mathrm{U}_{\mathrm{Tij}} \mathrm{W}_{\text {rti }}
\end{gathered}
$$

...where $\mathrm{K}, \mathrm{L}, \mathrm{M}$ and $\mathrm{N}$ are numbers of the items within SWOT analysis. Best ranked strategy is the one with the biggest value $\mathrm{V}_{\mathrm{j}}$.

\section{Description of the Value of the National Park Kopaonik}

National park Kopaonik belongs to I category, i.e, to the protected area of the international, national, i.e, of extreme importance for the Republic of Serbia. The area of the National park Kopaonik is important from the aspect of preservation of biodiversity, particularly areas important for preservation of plant species IPA area (Important Plant Areas), for preservation of diversity of birds IBA - (Important Birds Areas) and daily butterflies PBA- Prime Butterfly Areas [26]

As [27], municipalities on the territory of the national park Kopaonik experienced drop in economic activities and consequentially a status of „extremely undeveloped unit of local self-government have allotted to them" with the degree of development below $60 \%$ in relation to the national average. Previous research suggested that that National park Kopaonik and its protected zone can be classified as neglected mountain areas, according to criteria of regional classification of rural areas in the EU.

Building and increase in the number of existing accommodation capacities are necessary for the improvement of touristic offer on the given territory.
Deciding about the selection of the adequate project, when it comes to hotel building, is very important, because successfully carried out investment will lead to the return of the invested financial means. Talking in scientific sense, [28] suggest the use of MCDM approach, whose possibilities are still not completely recognized and tested in the area of choice of projects when it comes to hotel constructions. Namely, applicability has been show in the study as well as the efficiency of proposed framework which refers to the case of five kinds of hotels which should be built on the mountain Kopaonik.

\section{Research Results}

The first phase of research encompassed the survey of the existing literature (including also results of research in the past, reports, documents and strategies of different institutions) and the selection of all internal and external factors for the National park Kopaonik.

All the examinees, i.e, decision-makers, have been informed in detail about the aim of the research. The examinees voluntary participated in the research and were informed that the research is anonymous and that data will be used solely for the purposes of the research, necessary for writing this study. Experts have been chosen for decision-makers. Expert group included two sub-groups: representatives of competent institutions, and academic experts.

Representatives of competent institutions are employeed at the Institute for Protection of Nature of Serbia, State Enterprise for Forest Management "Srbijašume", Ministry of Trade, Tourism and Telecommunications of the Republic of Serbia, Ministry of Agriculture, Forestry and Waterpower Engineering of the Republic of Serbia and the Ministry of Environment Protection of the Republic of Serbia. Academic experts are employed at the: Faculty of Geography in Belgrade, Faculty of Mathematics and Natural Sciences in Novi Sad and the Faculty of Philosophy (Department for Geography) in Eastern Sarajevo.

The premise in definining of SWOT analysis was analysis of natural and anthropogenic characteristics, i.e., detailed analysis of geomorphologic, hydrologic, climate, ecologic and biologic characteristics, as well as analysis of tourism, agriculture, forestry, environment 
Table 6. SWOT analysis of the national park Kopaonik.

\begin{tabular}{|c|c|}
\hline STRENGTHS (S) & WEAKNESSES (W) \\
\hline $\begin{array}{l}\text { - S1 - high degree of biologic diversity (various ecosystems built of } \\
\text { numerous kinds and its communities) } \\
\text { - } \mathbf{S 2} \text { - } 1600 \text { kinds of plants ( } 11,9 \% \text { of Balkan high-mountain en- } \\
\text { demites) } \\
\text { - } \mathbf{S 3} \text { - thermal and mineral sources in surroundings of the national } \\
\text { park (Jošanica spa, Lukovo, Kursumlija spa etc.) } \\
\text { - S4 - flat Kopaonik ( } 1700 \mathrm{~m} \text { altitude), extraordinary beauty and } \\
\text { diversity of the landscape ( } 12 \text { geomorphological, } 6 \text { geologic and } 8 \\
\text { hydrologic objects of geoheritage of universal value) } \\
\text { - } \mathbf{S 5} \text { - villages, old watermills, and ski lodges and mountain eleva- } \\
\text { tions where traditional way of life is preserved have a specific } \\
\text { charm } \\
\text { - S6 - there are } 15 \text { immovable cultural goods in the space of Ko- } \\
\text { paonik } \\
\text { - } \mathbf{S 7} \text { - Josif Pancic's mausoleum (of the biggest Serbian botanis) on } \\
\text { the top of the Sky cabins }\end{array}$ & $\begin{array}{l}\text {-W1 - illegal building and development of touristic capaci- } \\
\text { ties in disagreement with plan - a big threat to preservation of } \\
\text { natural values in further development of tourism in Kopaonik } \\
\text {-W2 - inadequate treatment of natural values (negligence of } \\
\text { road ways, unrehabilitated mines, unrehabiliatated conse- } \\
\text { quences of NATO bombing) } \\
\text {-W3 - undeveloped offer of touristic product in the course of } \\
\text { the summer season } \\
\text { - W4 - undeveloped offer of ecology, cultural -historical, } \\
\text { health and ethno tourism } \\
\text { - W5 - non-existence of organization for planning, develop- } \\
\text { ment of product and coordination of integral touristic offer } \\
\text { - W6 - disharmony in building of touristic and general } \\
\text { infrastructure (on some locations accommodation capacities } \\
\text { greatly exceed capacities of general infrastructure) } \\
\text { - W7 - non-integrated management of protection of national } \\
\text { park and development of tourism }\end{array}$ \\
\hline OPPORTUNITIES (O) & THREATS (T) \\
\hline $\begin{array}{l}\text { - O1 - bigger touristic recognizability of Kopaonik in relation to } \\
\text { other touristic destinations in Serbia } \\
\text { - O2 - possibility of development of innovative products and inte- } \\
\text { grated mountain resort } \\
\text { - O3 - interests on the national and local level for firm support to } \\
\text { touristic development of Kopaonik } \\
\text { - O4 - trend of ecologic holidays based on nature } \\
\text { - O5 - cooperation with other regions clusters in Serbia with the } \\
\text { aim of attracting of visits to the wider region } \\
\text { - O6 - learning on positive experiences of other similar destinations } \\
\text { - O7 - significant entrepreneurial initiative - interest of domestic } \\
\text { and foreign investors }\end{array}$ & $\begin{array}{l}\text { - T1 - competition with mountain destinations in wider region } \\
\text { - T2 - unchanged legislative and management frameworks } \\
\text { - T3 - danger from devastation of space by (building not in } \\
\text { accordance with plan and unsustainable building and develop- } \\
\text { ment) } \\
\text { - T4 - lack of understanding of key rules of the game in tour- } \\
\text { ism, particularly by regional and local self-governments } \\
\text { - T5 - danger of extensive and unplanned use of natural } \\
\text { resources } \\
\text { - T6 - strategic determination on tourism of surrounding } \\
\text { countries } \\
\text { - T7 - perception of Serbia on international level as political } \\
\text { unstable country }\end{array}$ \\
\hline
\end{tabular}

Source: the authors

protection and demographic characteristics. Analysis of potential of analyzed space also includes cultural and historical heritage.

First, examinees have been invited to allot certain numerical values to every pair of factors in used model, by using Saaty's scale, with the aim of allotment of degree of importance, and then weight coefficients have been made for factors of models.

Calculating of weight indexes of criteria/ sub criteria is carried out in 4 steps:

1. Formation of matrix of comparison in pairs.

2. Calculation of sum of all the elements in every column.

3. Division of elements of every column with the sum of value of that column (the column obtained in the previous step).

4. Calculation of the sum of all elements by every order, and then determining of medium value (mean) of every line in the matrix. The column where obtained medium values are found is the column on the basis of which weight indexes are obtained of every criterion.

AHP procedure has also been used to determine the weight of the group (S, W, O and T) has also been used to determine the weight of the group. Best ranked elements are selected within every SWOT group, and then mutually compared. The values have been given to the weights of groups in Table 7. The degree of consistency of this matrix amounts to $\mathrm{CR}=0.044553$, which is an acceptable value, i.e., indicates to the fact that analysis is adequate and that there is no need for a new evaluation of weight criteria.

We will get resulting weights $\left(\mathrm{W}_{\mathrm{rsi}}, \mathrm{W}_{\text {rwi }}, \mathrm{W}_{\text {roi }}\right.$ and $\mathrm{W}_{\mathrm{rti}}$ ) by multiplying the weight of the elements of the group $\left(\mathrm{w}_{\mathrm{si}}, \mathrm{w}_{\mathrm{wi}}, \mathrm{w}_{\mathrm{oi}}\right.$ and $\left.\mathrm{w}_{\mathrm{ti}}\right)$ with the weight of a certain group $(\mathrm{S}, \mathrm{W}, \mathrm{O}$ and $\mathrm{T})$. Final results are also given in Table 7.

\section{Proposal of Strategies Based on TOWS Matrix}

The absence of strategies of development of ecotourism in the National park Kopaonik requests special care and gradual inclusion of ecotourism in programs of protection. Prioritization of implementation of defined strategies indicates to the order of necessary activities so that the National park Kopaonik from the 
Table 7. Global weight of criteria of SWOT analysis of the national park Kopaonik.

\begin{tabular}{|c|c|c|c|c|}
\hline SWOT group & $\begin{array}{l}\text { Weight of } \\
\text { the group }\end{array}$ & SWOT factors & $\begin{array}{l}\text { Weight of the } \\
\text { elements of the } \\
\text { group }\end{array}$ & $\begin{array}{l}\text { Resulting } \\
\text { weights }\end{array}$ \\
\hline \multirow[t]{3}{*}{ Strenghts } & \multirow[t]{3}{*}{0.556} & $\begin{array}{c}\text { S4 - flat Kopaonik (1700 m altitude), extraordinary beauty and } \\
\text { diversity of the landscape (12 geomorphological, } 6 \text { geologic and } 8 \\
\text { hydrologic objects of geoheritage of universal value) }\end{array}$ & 0.109 & 0.06060 \\
\hline & & $\begin{array}{l}\text { S3 - thermal and mineral sources in surroundings of the national } \\
\text { park (Jošanica spa, Lukovo, Kursumlija spa etc.) }\end{array}$ & 0.106 & 0.05894 \\
\hline & & $\begin{array}{c}\text { S1 - high degree of biologic diversity (various ecosystems built of } \\
\text { numerous kinds and its communities) }\end{array}$ & 0.102 & 0.05671 \\
\hline & & $\begin{array}{c}\text { S2 - } 1600 \text { kinds of plants ( } 11,9 \% \text { of Balkan high-mountain en- } \\
\text { demites) }\end{array}$ & 0.098 & 0.05449 \\
\hline & & $\begin{array}{l}\text { S5 - villages, old watermills, and ski lodges and mountain elevations } \\
\text { where traditional way of life is preserved have a specific charm }\end{array}$ & 0.055 & 0.03058 \\
\hline & & $\begin{array}{l}\text { S7 - Josif Pancic's mausoleum (of the biggest Serbian botanis) on } \\
\text { the top of the Sky cabins }\end{array}$ & 0.045 & 0.02502 \\
\hline & & S6 - there are 15 immovable cultural goods in the space of Kopaonik & 0.042 & 0.02335 \\
\hline \multirow{7}{*}{ Weaknesses } & \multirow{7}{*}{0.071} & $\begin{array}{l}\text { W1 - illegal building and development of touristic capacities in disa- } \\
\text { greement with plan - a big threat to preservation of natural values in } \\
\text { further development of tourism in Kopaonik }\end{array}$ & 0.019 & 0.00135 \\
\hline & & $\begin{array}{c}\text { W6 - disharmony in building of touristic and general infrastructure } \\
\text { (on some locations accommodation capacities greatly exceed capaci- } \\
\text { ties of general infrastructure) }\end{array}$ & 0.015 & 0.00106 \\
\hline & & $\begin{array}{c}\text { W7 - non-integrated management of protection of national park and } \\
\text { development of tourism }\end{array}$ & 0.009 & 0.00064 \\
\hline & & $\begin{array}{l}\text { W3 - undeveloped offer of touristic product in the course of the } \\
\text { summer season }\end{array}$ & 0.008 & 0.00057 \\
\hline & & $\begin{array}{l}\text { W5 - non-existence of organization for planning, development of } \\
\text { product and coordination of integral touristic offer }\end{array}$ & 0.007 & 0.00050 \\
\hline & & $\begin{array}{l}\text { W2 - inadequate treatment of natural values (negligence of road } \\
\text { ways, unrehabilitated mines, unrehabiliatated consequences of } \\
\text { NATO bombing }\end{array}$ & 0.006 & 0.00043 \\
\hline & & $\begin{array}{c}\text { W4 - undeveloped offer of ecology, cultural -historical, health and } \\
\text { ethno tourism }\end{array}$ & 0.005 & 0.00035 \\
\hline \multirow{7}{*}{ Opportunities } & \multirow{7}{*}{0.295} & $\begin{array}{l}\mathbf{O 1} \text { - bigger touristic recognizability of Kopaonik in relation to other } \\
\text { touristic destinations in Serbia }\end{array}$ & 0.109 & 0.03215 \\
\hline & & $\mathbf{O} 4$ - trend of ecologic holidays based on nature & 0.039 & 0.01150 \\
\hline & & $\begin{array}{c}\text { O7 - significant entrepreneurial initiative -interest of domestic and } \\
\text { foreign investors }\end{array}$ & 0.035 & 0.01032 \\
\hline & & $\begin{array}{c}\mathbf{O 3} \text { - interests on the national and local level for firm support to } \\
\text { touristic development of Kopaonik }\end{array}$ & 0.034 & 0.01003 \\
\hline & & O6 - learning on positive experiences of other similar destinations & 0.031 & 0.00914 \\
\hline & & $\begin{array}{c}\mathbf{O 2} \text { - possibility of development of innovative products and inte- } \\
\text { grated mountain resort }\end{array}$ & 0.024 & 0.00708 \\
\hline & & $\begin{array}{c}\text { O5 - cooperation with other regions clusters in Serbia with the aim } \\
\text { of attracting of visits to the wider region }\end{array}$ & 0.022 & 0.00649 \\
\hline
\end{tabular}


Table 7. Continued.

\begin{tabular}{|c|c|c|c|c|}
\hline \multirow{7}{*}{ Threats } & \multirow{7}{*}{0.078} & $\begin{array}{l}\text { T3 - danger from devastation of space by (building not in accord- } \\
\text { ance with plan and unsustainable building and development) }\end{array}$ & 0.023 & 0.00179 \\
\hline & & T5 - danger of extensive and unplanned use of natural resources & 0.019 & 0.00148 \\
\hline & & T2 - unchanged legislative and management frameworks & 0.008 & 0.00062 \\
\hline & & $\begin{array}{l}\text { T4 - lack of understanding of key rules of the game in tourism, } \\
\text { particularly by regional and local self-governments }\end{array}$ & 0.0074 & 0.00058 \\
\hline & & $\begin{array}{c}\text { T7 - perception of Serbia on international level as political unstable } \\
\text { country }\end{array}$ & 0.0071 & 0.00055 \\
\hline & & T1 - competition with mountain destinations in wider region & 0.006 & 0.00047 \\
\hline & & T6 - strategic determination on tourism of surrounding countries & 0.005 & 0.00039 \\
\hline
\end{tabular}

Source: the authors

present position would reach the level of recognizable ecoutorist destination. Strategies have been presented in continuation which will serve as a starting point to the decision-makers in NP Kopanonik for introduction of concept of ecotourism.

On the basis of objective consideration of the most important sub factors when it comes to strengths, weaknesses, opportunities and threats, the following strategies have been generated SO, ST, SW, WT based on TOWS matrix:

SO - Form a strategy which would promote a high degree of biologic diversity and bigger touristic recognisability of Kopaonik in relation to other destinations in Serbia.

The National park Kopaonik spreads on the highest and most maintained parts of mountain Kopaonik. It has been protected since 1981. on the surface of 11.809 ha. It has characteristics of high degree of biology diversity. It is ornamented by various ecosystems built from numerous kinds and their communities. Kopaonik is the most recognizable mountain destination and the most popular ski resort in Serbia and for several decades it has had the role of a leader in tourist development of mountain destinations of Serbia.

ST - Create a strategy that would use an adequate valorisation and protection of natural values of Kopaonik (natural conveniences of the mountain for development of winter and summer tourism) with the aim of prevention of degradation, irreversible disturbance and stopping the process of illegal building.

Kopaonik has been assessed as an area of extremely favourable characteristics for development of tourism. Climate characteristics, configuration of mountain and altitude enable development of quality product, of skiing and alternative winter products, and existing natural and cultural resources in Kopaonik give possibility for development of year-round diversified offer of touristic products. The created strategy would, with adequate valorisation and protection of natural values, prevent the process of illegal building, which is a big threat to quality of touristic destination Kopaonik.
WO - Form a strategy that would use bigger touristic recognisability of Kopaonik in relation to other destinations in Serbia, with the aim of prevention of illegal building and development of touristic capacities not in accordance with plan, which are a big threat to preservation of natural values in further development of (eco)tourism in the territory of NP Kopaonik.

Geomorphologic, climate, biogeographic and hydrographic values of Kopaonik must be kept in its original form or slightly modified form, which is from the aspect of whole ecotourism very important. Nature thus preserved and environment are a basic value which attracts potential tourists. Suggested strategy should use bigger recognisability of Kopaonik in relation to other destinations in Serbia and in that way prevent illegal building and development of tourist capacities not in accordance with plan.

WT - Form a strategy which would use administrative-legal mechanism of environment protection with the aim of prevention of illegal building and development of touristic capacities in disagreement with a plan.

The proposed strategy would implement existing plans and efficient carrying out of legal and by -law regulations, with the aim of prevention of illegal building, because further devastation can have a disastrous influence on the competitiveness of Kopaonik as a mountain destination, i.e., to its regional, even international rank of ambitions.

Before ranking of strategies, indexes of strategies have been determined $\left(\mathrm{E}_{\mathrm{sij}}, \mathrm{E}_{\mathrm{wij}}, \mathrm{E}_{\mathrm{oij}}\right.$ and $\left.\mathrm{E}_{\mathrm{tij}}\right)$ by use of AHP methods and are illustrated in Table 8.

In Table 8, values of coefficients of efficiency of strategies have been illustrated - SO, ST, WT and WT. The abovementioned strategies are compared in relation to (SWOT analysis) of the abovementioned strength, weaknesses, opportunities and threats. The way in which they are compared is characteristic for AHP analysis: which of the two strategies is preferred (according to Saaty's scale of comparison) in relation to the factor of threat mentioned in the SWOT analysis 
Table 8. Coefficients of efficiency of certain strategies.

\begin{tabular}{|c|c|c|c|c|}
\hline & $\mathrm{SO}$ & ST & WO & WT \\
\hline $\mathrm{Es}_{1}$ & 0.556 & 0.295 & 0.078 & 0.071 \\
\hline $\mathrm{Es}_{2}$ & 0.556 & 0.295 & 0.078 & 0.071 \\
\hline $\mathrm{Es}_{3}$ & 0.556 & 0.295 & 0.078 & 0.071 \\
\hline $\mathrm{Es}_{4}$ & 0.556 & 0.295 & 0.078 & 0.071 \\
\hline $\mathrm{Es}_{5}$ & 0.369 & 0.369 & 0.131 & 0.131 \\
\hline $\mathrm{Es}_{6}$ & 0.369 & 0.369 & 0.131 & 0.131 \\
\hline $\mathrm{Es}_{7}$ & 0.369 & 0.369 & 0.131 & 0.131 \\
\hline $\mathrm{Ew}_{1}$ & 0.071 & 0.347 & 0.152 & 0.429 \\
\hline $\mathrm{Ew}_{2}$ & 0.232 & 0.492 & 0.138 & 0.138 \\
\hline $\mathrm{Ew}_{3}$ & 0.232 & 0.492 & 0.138 & 0.138 \\
\hline $\mathrm{Ew}_{4}$ & 0.232 & 0.492 & 0.138 & 0.138 \\
\hline $\mathrm{Ew}_{5}$ & 0.232 & 0.492 & 0.138 & 0.138 \\
\hline $\mathrm{Ew}_{6}$ & 0.086 & 0.292 & 0.292 & 0.331 \\
\hline $\mathrm{Ew}_{7}$ & 0.126 & 0.362 & 0.101 & 0.411 \\
\hline $\mathrm{Eo}_{1}$ & 0.544 & 0.112 & 0.254 & 0.090 \\
\hline $\mathrm{Eo}_{2}$ & 0.232 & 0.492 & 0.138 & 0.138 \\
\hline $\mathrm{Eo}_{3}$ & 0.293 & 0.293 & 0.207 & 0.207 \\
\hline $\mathrm{Eo}_{4}$ & 0.293 & 0.293 & 0.207 & 0.207 \\
\hline $\mathrm{Eo}_{5}$ & 0.293 & 0.293 & 0.207 & 0.207 \\
\hline $\mathrm{Eo}_{6}$ & 0.293 & 0.293 & 0.207 & 0.207 \\
\hline $\mathrm{Eo}_{7}$ & 0.293 & 0.293 & 0.207 & 0.207 \\
\hline $\mathrm{Et}_{1}$ & 0.293 & 0.293 & 0.207 & 0.207 \\
\hline $\mathrm{Et}_{2}$ & 0.293 & 0.293 & 0.207 & 0.207 \\
\hline $\mathrm{Et}_{3}$ & 0.077 & 0.285 & 0.285 & 0.353 \\
\hline $\mathrm{Et}_{4}$ & 0.293 & 0.293 & 0.207 & 0.207 \\
\hline $\mathrm{Et}_{5}$ & 0.166 & 0.498 & 0.139 & 0.197 \\
\hline $\mathrm{Et}_{6}$ & 0.398 & 0.199 & 0.167 & 0.236 \\
\hline $\mathrm{Et}_{7}$ & 0.398 & 0.199 & 0.167 & 0.236 \\
\hline
\end{tabular}

Source: authors

or, which of those 2 observed strategies is preferred in relation to the factor of chance и and enables their better use and for how much?

Value of every strategy has been calculated:

$$
\begin{aligned}
\mathrm{V}_{\mathrm{j}} & =\sum_{\mathrm{i}=1}^{\mathrm{K}} \mathrm{U}_{\mathrm{Sij}} \mathrm{W}_{\mathrm{rsi}}+\sum_{\mathrm{i}=1}^{\mathrm{L}} \mathrm{U}_{\mathrm{Wij}} \mathrm{W}_{\mathrm{rwi}} \\
& +\sum_{\mathrm{i}=1}^{\mathrm{M}} \mathrm{U}_{\mathrm{Oij}} \mathrm{W}_{\text {roi }}+\sum_{\mathrm{i}=1}^{\mathrm{N}} \mathrm{U}_{\mathrm{Tij}} \mathrm{W}_{\mathrm{rti}}
\end{aligned}
$$

strategies have been ranked and the results are illustrated in Table 9.

The obtained results illustrated in Table 9 by the use of AHP and SWOT methodology for prioritization of strategies of sustainable development of ecotourism at the National park Kopaonik, indicate to the following order of strategies:

\section{SO-ST-WT-WO}

After the analysis of the obtained results, it is obvious that experts were objective and coexistent 
Table 9 . Ranking of strategies of development of ecotourism at the mational park Kopaonik.

\begin{tabular}{|c|c|c|}
\hline Strategy & Value & Rank \\
\hline SO & 0.374 & 1 \\
\hline ST & 0.327 & 2 \\
\hline WO & 0.136 & 4 \\
\hline WT & 0.162 & 3 \\
\hline
\end{tabular}

Source: the authors

in assessment, which indicates to correctness of implemented methodology.

\section{Discussion of Results}

Implemented approach encompassed the survey of current condition of potentials of research space, i.e., the National park Kopaonik. By observation of realistic situation on the basis of key internal and external factors of the abovementioned national park, SWOT analysis has been done which encompassed the most important parameters. SWOT analysis is the starting point, for defining of strategy of development of ecotourism of research space.

Integrated AHP-SWOT model of multicriteria decision-making on the basis of previously defined SWOT factors and subfactors, i.e., criterion/sub criterion has been used for prioritization of generated strategies. Formulated strategies and prioritization of their implementation indicates to order of necessary activities so that NP Kopaonik would reach the level of recognizable eco-touristic destination. The final result as an order of strategies can serve as a starting point for introduction of concept of ecotourism and in any other protected area.

By implementation of a defined model which is based on SWOT analysis, proposed strategies encompass maximization of strengths and opportunities, with minimizing weaknesses and threats. The obtained results indicate to the fact that the future development of ecotourism at the national park Kopaonik will be most influenced by the extraordinary beauty and diversity of the area (12 geomorphologic, 6 geologic, and 8 hydrologic forms of geoheritage of universal value) of Flat Kopaonik (1700 m altitude) and bigger touristic acknowledgement of Kopaonik in relation to other destinations in Serbia. It is necessary to reduce illegal building to the minimum and development of touristic capacities which are not in agreement with the plan, which are a big threat to preservation of natural values, in further development of tourism in Kopaonik and pose a threat from devastation of space. As a priority strategy for development of ecotourism in this national park, SO strategy based on TOWS matrix has been singled out. SO strategy would promote high degree of biological diversity and bigger touristic recognisability of Kopaonik in relation to other destinations in Serbia. In the course of implementation of SO strategy, it is essential to start with implementation of WO strategy so that key weaknesses relating to illegal building should be overcome, as well as development of touristic capacities not in agreement with the plan, which are a big threat to preservation of natural values, in further development of (eco)tourism in the territory of NP Kopaonik.

\section{Conclusions}

By combining SWOT analysis and Analytical hierarchical process, the process of strategic decisionmaking can be improved, which is demonstrated on a real example of selection of optimum strategy of development of ecotourism.

This work is an integrated approach of combination of AHP methodology and SWOT analysis. The problem classic SWOT analysis is facing with is inability of analytical approach in assessment of the relative importance of SWOT factor. By comparison of pairs by means of AHP methodology, their relative importance is determined, which improves information ground and enables more detailed description of the current condition of research space.

Supporters of ecotourism as a strategy of development include international financial institutions, global organizations for environment protection, world touristic companies, local communities, as well as individuals who consider themselves eco-tourists. The research space has at disposal quite favourable potential that provides a possibility of use in respect of development of ecotourism. However, the biggest part of this space is not adequately used, as regards possibilities it has at disposal, nor its potential has been valorised in the right way.

On the basis of all the abovementioned facts, it can be concluded that the key scientific contribution of this work is the improvement of the system of strategic decision-making at national parks and other protected natural areas. The study highlights the importance and convenience of implementing of AHP- SWOT in the subject and similar areas.

The study is useful in theory and practice of the development of management of protected areas. Contemporary methods for support of the decisionmaking process, among which AHP is one of the most reliable ones, enable scientifically based and responsible decision-making which really can be implemented.

\section{Conflict of Interest}

The authors declare no conflict of interest. 


\section{References}

1. SANATAREM F., CAMPOS J.C., PEREIRA P.,HAMIDOU D., SAARINEM J., BRITCO J.C. Using multivariate statistics to assess ecotourism potential of water-bodies: A case-study in Mauritania. Tourism Management, 67, 2018.

2. ABDULLAH N., RAMAMOORTY T. Diversified cultures via tourism as sabah'h heritage: a modelling approach using analytic hierarchy process. Asian Journal of Arts, Culture and Tourism, 1, 1, 2019.

3. MAKSIMOVIĆ M., UROŠEVIĆ S., STANUJKIĆ D., KARABAŠEVIĆ D. Selection a development strategy of mining tourism based on the grey relation analysis. Mining \& Metallurgy Engineering Bor, 1, 2016.

4. KARABAŠEVIĆ D., STANUJKIĆ D., DJORDJEVIĆ B., STANUJKIĆ A. The weighted sum preferred levels of performances approach to solving problems in human resources management. Serbian Journal of Management, 13, 1, 2018.

5. AFSHARI A.R., VATANPARAST M., ĆOĆKALO D. Application of multi criteria decision making to urban planning - a review. Journal of Engineering Management and Competitiveness (JEMS), 6, 1, 2016.

6. MONSOUR S., AL-AWHADI T., AL-HATRUSHI S. Geospatial based multi-criteria analysis for ecotourism land sustability using GIS \& AHP: a case study of Masirah Islands, Oman. Journal of Ecotourism, 18, 2019.

7. KABASSI K., MARTINIS A., PARADATOU A. Analytic hierarchy process an inspection evaluation national park's websites: the case study of Greece. Journal of environmental management and tourism, 10, 5, 2019.

8. PODAWCA K., POWLAT-ZAWRZYKRAJ A. Diversifying tourism in municipalities within impact areas of national parks. Polish Journal of Environmental Studies, 27, 5, 2018.

9. YEE T.B., RAMLAN R., HASSAN R., SHURI S.R.M., MOKHTAR R. The Evaluation of third party hotel booking website performance using analytic hierarchy process (AHP). Journal of Advanced Research in Dynamical and Control Systems, 10, 7, 2017.

10. ARSIĆ S. Integral SWOT-ANP-FANP model for prioritization of strategies for sustainable development of ecotourism in Djerdap National Park. Technical faculty: Bor, Serbia, doctoral dissertation, 2017, [In Serbian].

11. BIANCO S., MARCIANÓ C. Using an hybrid AHPSWOT method to build participatory ecotourism development strategies: the case study of the Cupe Valley natural reserve in Southern Italy. International Symposium on New Metropolitan Perspectives, Conference paper, 2018.

12. DEMIR S., ATANUR G. The prioritization of naturalhistorical based ecotourism strategies with multiplecriteria decision analysis in ancient UNESCO sity: Iznik - Bursa case. International Journal of Sustainable Development \& World Ecology, 26, 4, 2019.
13. BALIST J., HEYDARZADEH H., SALEHI E. Modeling, Evaluation and zoning Marivan country ecotourism potential using fuzzy logic, FANP and TOPSIS. Geographica Pannonica, 23, 1, 2019.

14. OLGUN R., YILMAZ T. A'wot method in determination of sustainable strategic objectives towards open green areas in the medium sized cities, the case of Niğde, Turkey. Fresenius Environmental Bulletin, 28, 7, 2019.

15. SASANA H., NULCAHYANTO H., NOVITANINYTYAS I. Development strategy in world heritage tourism in Indonesia. African Journal of Hospitality, Tourism and Leisure, 8, 5, 2019.

16. KIŞI N. A Strategic approach to sustainable tourism development using A'WOT hybrid method: A case study of Zonguldak, Turkey. Sustainability, 11, 4, 2019.

17. FAN T., XUE D.Q. Sustainable development of cultural industry in Shaanxi province of Northwest China: A SWOT and AHP analysis. Sustainability, 10, 8, 2018.

18. GUO X., YAN H., YUAN W. Research on China's rural development strategy based on SWOT-AHP analysis. International Research in Economics and Finance, 3, 1, 2019.

19. MONDAL M.S.H. SWOT analysis and strategies to develop sustainable tourism in Bangladesh. UTMS Journal of Economics, 8, 2, 2017.

20. SAATY T.L. Decision making with the analytic hierarchy process. International Journal Services Sciences, 1, 1, 2008.

21. TROUNG H.N., JANG W.J. Evaluating the competition of marine tourism industry among major countries in Southeast Asia using AHP method. American Journal of Environmental and Resource Economics, 4, 3, 2019.

22. OSUNA E.E., ARANDA A. Combining SWOT and AHP techniques for strategic planning. ISAHP, 2007.

23. KOTLER P. Marketing, management, millennium edicton. Customeditton for University Psychology, 15, 2002.

24. WICKRAMASINGE V., TAKANO S. Application of combined SWOT and analytic hierarchy process (AHP) for tourism revival strategic marketing planning: A case of Sri Lanka tourism. Journal of the Eastern Asia Society for Transportation Studies, 8, 2010.

25. ŠLJIVOVIĆ M. Application of combined SWOT-AHP methods in planning a tourism development strategy by example for Timok region. Megatrend Revija, 14, 1, 2016.

26. Expert basis for drafting the law on national parks Kopaonik National Park. Zavod za zaštitu prirode Srbije: Beograd, Srbija, 2015 [In Serbian].

27. BRANKOV, J., PENJIŠEVIĆ I., ĆURČIĆ N., ŽIVANOVIĆ B. Tourism as a factor of regional development: community perceptions and potential bank support in the Kopaonik national park (Serbia). Sustainability, 11, 22, 2019.

28. POPOVIĆ, G., STANUJKIĆ D., KARABAŠEVIĆ D. A framework for the evaluation of hotel property development projects. International Journal of Strategic Property Management, 23, 2, 2019. 